Taltua, Vol. 1, No. 1, January-June 2009, pp. 1.10

ISSN 0975-332X | https://doi.org/10.12726/tjp.1.1

\title{
Tativa
}

JOURNAL OF PHILOSOPHY

\section{PROCESS, RELIGION, AND SOCIETY}

John B. Cobb, Jr.

l am greatly honored to have been asked to present a keynote address on this topic and af this location. I once spent a month teaching here in Bangalore and found it a delightful city. It has now become one of the great centers of the global economy. Although I am not an admirer of the global economy, it is exciting to see the transformation of this city. I am grateful to Dharmaram College, with its allied institutions - Christ University (CU) and Dharmaram Vidya Kshetram (DVK) for hosting this conference, and $\mathrm{I}$ am hopeful that religious thinkers, social activists and educationists in India will find process thought useful to them. I am sure that their response to, and development of, process thought will be of value to the whole international process community.

I have been asked to address the conference theme quite directly; so my address will be in three parts: process, religion, and sociely.

\section{Whitehead and 'Process'}

Although in this section I will speak primarily of process philosophy, it is important to indicate from the beginning that the philosophy in which process thinkers are interested does not belong to one academic department in distinction from others. Like traditional philosophy in the West and certainly also in India, it is a way of thinking seriously about all the issues that concern human beings.

In the West in recent times, philosophy has made of itself a distinct academic discipline. By doing so it has achieved a certain rigor, but it has lost most of its 
relevance to the issues humanity now faces. In general it seeks to separate itself from religious thought and from social thought as well. The title of this conference rightly indicates that process philosophy is quite different in these respects.

Instead of limiting ourselves to careful phenomenological description, or to the analysis of language, or to the study of epistemology separated from scientific considerations, process thinkers raise the whole range of classical philosophical questions. Much of contemporary process thought has developed in direct engagement with the physical sciences. Religious people have felt its immediate relevance. Some of its most important expressions are with respect to social issues. Indeed, one of its problems in gaining a place in universities is that it does not fit in any existing "discipline." II finds all of them shaped by philosophical assumptions with which it disagrees, including the assumption that real knowledge can be boxed into separate departments.

This does not mean that process philosophers avoid rigorous phenomenological description. Alfred North Whitehead's book, The Concept of Nature, can well be understood as a masterpiece of phenomenology, and similar descriptions occur elsewhere in his writings. But in the full development of his philosophy, he removed the brackets that separated phenomenology from ontology. He certainly recognized the importance of language and gave serious altention to it. But he did not see language as a self-contained whole with no reference beyond itself. Instead he studied it in the larger context of nature, a nature that includes human beings. Similarly, the question of how we know the world in which we live was for him a central issue. But his answer integrated phenomenological and physiological considerations in a larger whole.

Hence, one distinctive point to make about process thought is that it is a renewal of the classical tradition of Western philosophy. It renews this tradition not be asserting the same doctrines as major figures of the past, but by engaging in fresh reflection on the wide-ranging issues that philosophy traditionally treated. In doing this, it is guided by new developments especially in mathematics and the physical sciences but also in philosophy itself. It tends to accent philosophical ideas that played a subordinate role in the fradition, seeing the need now to give them a central place.

The label "process" that is attached to this form of philosophy points to a basic illustration of this shiff. Thinkers have always recognized that there is both change and permanence in the world. Whitehead himself quotes from a Christion hymn: "abide with me, fast falls the evening tide." This recognition leads to such dualities in thought as becoming and being, events and objects, or process and substance. With few exceptions, the Western tradition has given precedence to being, objects, and substance over becoming and process. 
Today the most influential form of this precedence is the one that is built into the dominant conceptuality of the sciences. The world view underlying most scientific theory is still one of matter in motion. For a long time this "matter" was identified with what physicists called "atoms." These were thought of as little lumps of matter and given that name on the assumption that they were physically indivisible. The goal of physics was to explain all events and all phenomena in terms of the motions of atoms.

When these so-called atoms were split, the first assumption was that the error had only been to locate the lumps of matter that moved at too large a level. The "particles" into which they were split were assumed to be the tiny lumps of matter of which the world is composed. However, we all know that this model does not work. This failure of materialism has led to renewed speculation about the nature of reality, but the major schools of recent philosophy have avoided this speculation by declaring "metaphysical" questions to be meaningless. The result has been that the vast majority of scientists continue to operate as if the view of the world as matter in motion were satisfactory.

A few philosophers have proposed that metaphysical speculation is important. They think that nature would be better understood if we took becoming, events, and processes as basic instead of being, objects, and substances. Those who make this shift become process thinkers. It turns out that this metaphysical shift has ramifications for life and thought in all fields.

I hove spoken as if process thought arose from developments in physics. These have been important contributors to the increase and development of process thought in the twentieth century. But in India and East Asia, process thought developed much earlier quite independently of recent developments in science. In the West it can be traced back to Heraclitus. The philosophy of David Hume left us with a form of process - a flux of sensony data and little else. Friedrich Hegel is probably the most influential process thinker in the modern world.

Historical thinking, to which Hegel contributed greatly, emphasizes process in the affairs of human beings. Evolutionary thought locates historical processes in the larger context of natural ones. In the twentieth century Henri Bergson and William James led the way philosophically in moving to process thinking. What is surprising is that philosophy and the sciences have not more deeply incorporated their own implications. It seems that this conservatism has been made possible by the move to exclude metaphysics from acceptable scientific and philosophical discourse.

The Whiteheadian form of process thought, which has inspired the series of international conferences of which this is the seventh, emphasizes "relationality" as 
much as "process." Bernard Loomer, who introduced the label "process philosophy," later called it "process-relational" philosophy. The accent on relations also has roots in science as well as in other areas.

In science the idea of a field has become important. A field is composed of the events that make it up, but these events are what they are because of their locus in the field. They are the coming together of the field at some locus within it. The individual events are the unification of the influences of the other events constituting the field.

Thinking of events as largely constituted by the contexts in which they occur points to a contrast of Whitehead's process thought and the substance-attribute thinking that remains so widespread. The primary analysis of a unitary event, what Whitehead calls an "actual occasion," is not into its essence and its accidents but into its relations to other events, what Whitehead calls "prehensions." The process of becoming of an actual occasion is its synthesis of relations to other events.

Since, at least in the West, this shift is a deep reversal of received habits of thought, I will stay with it a moment longer. There is not something already given that then relates to the world in one way whereas it might have related in onother. The event only exists as the act of creatively synthesizing its relations. We may think of the completion of this act as "a being," but this being plays its role in other beings as the dalum of new relations that they integrate.

Those of you who are familiar with the work of the great Indian thinker, Nagariuna, will recognize this way of thinking. There is no subject that acts prior to the acting. The acting constifutes the subject. Buddhists speak of pratitya samutpada, which we often translate as "dependent origination." Whitehead writes of the many becoming one. There is no substance underlying this process, but the process of becoming one is fully real.

\section{Whitehead and Religion}

This vision of reality has profound implications for religious understanding. Much religious thought focuses on human beings and what makes them whole or authentic. Most Westerners have thought of themselves, like other things, as substances that have particular, changing attributes and relations. In this long-dominant tradition, the substance underlying the change is offen called the "soul;" in recent times, the "self." It is this soul or self that one hopes will be "saved." Sometimes this "salvalion" is understood to be based on a divine judgment that comes after one dies. Sometimes it is understood as the healing and fulfillment of life here and now. 
When the metaphysics is changed, so is the understanding of the self. There is no unchanging self underlying the flow of experience. The flow of experience is the actual process in itself. The self is to be found and identified within that process. That process largely consists, moment by moment, of the creative synthesizing of relations to one's own past, one's body, and other people. The self cannot be separate from the world and especially from other human beings. The idea of a purely individual salvation that does not involve others does not fit well with this way of thinking.

In many ways this understanding is congenial to the canonical scriptures of Judaism and Christianity. They tell stories far more than describe or analyze objects. Relationships play a central role. The command to love one's neighbor as oneself overcomes the idea of a primarily private salvation. Paul tells his followers that they are members one of another. Jesus proclaims the basileia theou, which I like to translate as the "divine commonwealth." However it is translated (the usual translation being the Kingdom of God) it is certainly not a private salvation whether in this life or beyond.

As Christianity spread in the Greco-Roman world, it assimilated Greek philosophical concepts and inferpreted its Hebrew heritage in those terms. These terms were far more sophisticated than any philosophical ideas that could be gleaned from the Bible, but at very deep levels they led to quite different ways of thinking about salvation. Whereas the Bible locates individuals in communities, Christianity came to emphasize the individual in transcendence of human community. Christians focused on the "immortal soul" of Plato rather than the fully embodied personal beings of the Bible. Salvation was increasingly considered individualistically and "spiritually," separate from society.

During the rise of Christianity, the Epicureans and Stoics were influential in defining salvation. In both cases, they prized human autonomy. If one related deeply to others, then what happened to others became important to one's own well-being. Also one cared how others thought of one. One thereby set oneself up for disappointment and suffering. The less one was dependent on others the more one had control of one's own destiny, and the better off one was. This Greek view is deeply different from the biblical call to love others, but it had its influence within Christionity.

Perhaps the greatest influence was on thought about God. Christians wanted to affirm God's perfection, and they were often embarrassed by stories about God in their scriptures. They learned to reject any literal reading of such stories. We can certainly appreciate the avoidance of the extreme anthropomorphism found in some of these stories. But the Greek influence went much further. 
In the Bible in general, and certainly in the teachings of Jesus and Paul, perfection consisted in the perfection of love. Human beings were to love others as themselves and to love God whole-heartedly. But as the Stoics and Epicureans saw, and Aristofle as well, love makes one vulnerable. The perfect condition for many Greeks was invulnerability. If God is perfect, God cannot be affected by what goes on in the world. God is then the perfect substance with no changing aitributes. Thus God is "impassible" and "immutable." Although the church never went so far as to deny that God loves the world, its teaching of divine perfection made clear that God's love is totally different from human love, totally mysterious.

Of course, popular piety always retained some sense of people being loved by God. But as long as the dominant style of thought remained substantialist, it was difficult to make sense of this biblical intuition. The adoption of process metaphysics makes it possible to release biblical thinking on this point from its bondage to Greek metaphysics. Perfection for Whitehead is the optimum inclusion of others in the constitution of the self. A human experience can include very little, but the divine experience includes all others. Perfection includes total vulnerability in this sense. Everything that happens adds to the divine experience and thus to the divine knowledge as well. However, in the totality of the divine life, God includes sinful human intentions without sharing those intentions. God includes human suffering, but even when humans are overwhelmed by that suffering, God is not. Even a human parent can have great empathy for a child who is self-destructive and miserably lonely without becoming self-destructive and miserably lonely. God is ideally empathetic to all creatures. That is, God is pure compassion.

Process theology, following Whitehead, breaks with the dominant tradition in another way as well. For process theologians the strict notion of divine omnipotence, that is, that God has all the power and makes all the decisions, makes no sense at all. Real power is the ability to influence other powerful beings. If there are no beings with power other than God, the whole notion of power collapses. For process thought, every event whatsoever exercises power by making a difference in what happens subsequently. Certainly, human beings exercise great influence on others.

Process theologians affirm that God has ideal power, that is, the power to influence everything in an ideal way. God's power is expressed in liberating and empowering creatures and calling them to exercise liberating and empowering power foward others. This is more characteristic of biblical accounts than the notion of total control over everything that happens. We are impressed that the frequent appearance of the word "almighty" in the English translations of the biblical text does not reflect anything in the original Hebrew. It expresses, instead, prejudices of the translators, 
especially those of St. Jerome as expressed in the Vulgate, the Latin translation of the Hebrew and Greek scriptures.

In short, process metaphysics opens the door to taking seriously the radically relational character of God and the world and of human beings to one another to which the Bible testifies. Process theologians find this to be a great gain. Although change of this depth is strongly resisted by many Christians, it has gained considerable ground.

Whitehead's metaphysics provides another possibility that many Westerners find difficult to accept. Whitehead distinguishes between God and crealivity. Creativity is the "ultimate." In Aristotelian terms, it is the ultimate "material cause" of all things. It is that of which all things are ultimately constituted. It has many of the characteristics that the tradition attributed, mistakenly, we believe, to God. That is creativity is "absolute." It is not affected by anything that happens. Hence it is impassible and immutable.

Although creativity plays the role of an Aristotelian "material cause," the word "material" is highly misleading. In Whitehead's view, things are not constituted of matter, which from the time of the Greeks has been understood to be passive and inert. Physics shows that energy is more fundamental than mass, which is the closest physicists come to speaking of matter. Energy is neither passive nor inert.

In philosophical terms, every event is constituted by an act, the act of creatively synthesizing what it can of the world given for if. Whitehead says that creativity is "the many becoming one and being increased by one." Every entity, that is, every event or actual occasion is an instance of creativity. This is true even of God whose life is a continual creative integration of the world.

Creativity plays the role in Whitehead that "Being Itself" has played in the Western tradition. "Being liself" has sometimes been understood as Godhead in distinction from God. It is the impersonal absolute beyond all characteristics and equally present in everything. In the East it is like the nameless "Tao" and some versions of Brahmon and Buddha nature. God, on the other hand, is more like the $L i$ of Confucianism, the deity of Ramanuja, and the Sambhogakaya of Mahayana Buddhism. When we view matters in this way, we need not argue whether God is personal or impersonal. There is an impersonal ultimate and there is also God. In both East and West, each has had its devotees. The realization that we are instantiations of the ultimate need not be in opposition to our worship of God and our acceptance of God's grace. 


\section{Whitehead and Society}

The religious life that recognizes how we are bound up with one another in community cannot be indifferent to society. When we understand that we are persons-incommunity we cannot seek our own well being in separation from that of others. Hence, as in so many cases, religious concerns and social concerns cannot be kept separate.

The substantialist habits of thought of the West have made it difficult to understand social relations in any other than contractual terms. Our traditional political and economic theories are largely couched in this way. Margaref Thatcher is famous for expressing this sensibility sharply. When asked about her concern for society, she responded that there is no such thing. In the modern Western imagination there are only separate individuals.

If one puts on process-relational glasses, this picfure changes dramatically. We do not see individuals each with particular self-interest coming to agreement on how to live together. Instead we see communities in which children gradually develop their individual personhood. They become persons because life in healihy community encourages this individualization. As individuals they contribute to the community of which they are a part. In general the best way to help individuals is to improve the communities of which they are part.

The difference can be seen quite vividly in alternate development strategies. Many nongovernmental organizations seeking to help economically disadvaniaged people to develop approach this through "community development." They invite the people of a village to discuss their needs as a community and to establish priorities. Perhaps the village decides that it would benefit most from having water available locally. The NGO may then work with the village to dig a well. The oim will be for the villogers to do most of the work and therefore to understand the well and have complete ownership and responsibility. If a pump is necessary, the mechanism should be as simple and understandable as possible, so that it too can be truly owned by the village.

Or their chief problem may be that firewood for cooking can only be found at a great distance. Solar cookers can reduce the need, and a woodlot may be developed locally. Again the people in the village must have complete understanding and ownership of what they do and use.

If the well or the solar cookers save hours of time for some of the villagers, there may be further discussion of what new projects can be taken on by the village. 
Gandhi, I understand, thought that the sewing machine would provide useful employment that would improve the economic condition of the villagers. If the sewing machines increase the income of the village, the next discussion will be what that income would make possible. Healthy development would thus be from the bottom up. This is the kind of growth that makes sense from the point of view of process thought.

Unfortunately, the dominant pattern of development has been determined by the dominant economic theory, which is based on the received metaphysics. In this theory community plays no role at all. The only human relations considered are contractual. Instead of cooperative work in community, it pictures competition among individuals who aim to better their respective lots. This universal competition for economic goods for individuals drives development.

Since the goal is increased total production, the means is industrialization. Industrialization organizes labor so as to increase total product and it replaces human labor with fossil fuels. There is little concern for the conditions of labor, and none for human dignity. Theoretically individuals are free to seek the jobs they want, but proctically there is little choice. Labor unions are viewed with disfavor since they inhibit the freedom of management to take actions that increase production.

This method of development "works." It achieves its goal of increasing production. But it does so at a great cost. Although eventually workers may receive better pay, they typically go through a period of shameless exploitation for decades before this happens. The separation of the wealthy capitalists and the impoverished workers destroys communily between them. Meanwhile little real community develops among the workers or among the capitalists. Further, on the whole industrial labor is tedious, and in comparison with that of the farmer or artisan it provides little personal satisfaction. In short, this form of development succeeds by its own narrow definition of the goal; it increases the total product available. But it destroys existing community, and it usually reduces the dignity and autonomy of life of its workers. It increases goods and services, but it typically reduces human happiness, which, in process perspective, is more a function of relationships than of consumption or ownership of goods.

Process thought affirms the continuity between human beings and the rest of nature. Just as we are constituted by relations with other people, we are also constituted by our relations with other parts of nature. Thus process thought adds to the concern for human community a concern that people and their communities be a part of a still larger notural system, one that includes living beings of other species and 
inanimate nature as well. Authentic development should be concerned about this larger system and establish forms of human action that can function sustainably within it. Bottom-up development has the potential of doing this, even though it sometimes fails. There is virtually no possibility for a world brought into being by the global economy, which aims at "sustainable growth," based on top-down development, to become sustainable. It is too closely bound to the standard economic model.

Just as the standard economic model has no place for human community, so also it has no place for the natural world. If it considers this at all, it is only in terms of notural resources, and even these play a trivial role. It is assumed that they are infinite, since technology can replace declining resources with alternatives. Recently, at the periphery, the limitations of this assumption have been acknowledged, but the basic form of global industrial development continues unabated in its ecological destructiveness. There is still a widespread assumption that if industrial society creates sufficient artificial wealth it will be able to cope with any problems caused by pollution, resource exhoustion, and weather change. This assumption is disastrously false.

To declare that our present global economy is unsustainable is not to point out a weakness that can be balanced by noting its strengths. If it is unsustainable, it will collapse.The world that this collapse will leave in its wake will be drastically impoverished in comparison with the world that existed even half a century ago. The danger is that its collapse will bring about a dramatic loss of global population, that means, massive deaths.

I have spoken in strong language parly to counter the supposition that little is at stake in philosophical debates. Many people in the West think that metaphysical questions are of interest only to a few out-of-date intellectuals. From the perspective of process thought, on the contrary, the unrecognized metaphysics that shapes our academic disciplines, and through them our public policies are damaging us spiritually and is leading to global catastrophes of unprecedented proportions.

We believe that a fundamental change in our understanding of our selves and our world could lead to change in the recommendalions that emanate from our "experts," and through that to change in our economic and social behavior. This change might reduce the extent of the suffering toward which our current practices, guided by our current theories, are leading us. Accordingly, our struggle is both for the soul and for the physical and social health of the planet. 